\title{
American Pediatric Society's 2010 John Howland Award Acceptance Lecture: Some Things Considered
}

\author{
CHARLES R. SCRIVER \\ Departments of Human Genetics and Pediatrics, McGill University, Montreal, Quebec H3H 1P3, Canada
}

Yesterday is history

Tomorrow is a mystery

Today is a gift

And we call it "the present"

-(Attributed to Eleanor Roosevelt)

$\mathrm{T}$ The Howland Award is indeed a gift, and I am most grateful to be its recipient this year. Russ Chesney was extremely generous in the things he said about me and I receive them as another gift-while assuming that most of his remarks are truthful.

Now is a good moment to thank my nominators and the selection committee for their work and for their decision and to thank the staff of the American Pediatric Society for making life so pleasant during this marvelous occasion.

For the Howland Award Acceptance Lecture, I spoke without a written text, aided only by a few PowerPoint slides. This written version is the result of memory recall, fallible as it is, many months later. Its organization here is my attempt to capture the principal themes of the talk.

\section{Part I: "I Am a Part of All That I Have Met"}

Russ Chesney has identified many of the influences that have been acting on myself through the years, and on the work being celebrated now; to which, I would add the following: I have had a "job"- a lifelong adventure, which I loved and pursued both at McGill University and at the Montreal Children's Hospital; at both places under benevolent auspices. Otherwise, the most significant influence on me has been a partner whom I have loved ever since we met as teenagers. To be able to love what you do and to be loved while doing it is truly a gift.

I have had many, many mentors; Barton Childs, who died in February of this year, was a very special mentor and friend and I dedicate this talk to him. And then, there are the colleagues and the students whose hard work, imagination, and collective talents have made the whole of our work greater than the sum of its parts; in fact, you are honoring those persons today. Finally, and as important as any other influence, I recognize that chance and opportunity have been very kind.

Received March 10, 2011; accepted March 10, 2011.

Correspondence: Charles R. Scriver, M.D., C.M., D.Sc.(Hon), F.R.S., Montreal Children's Hospital Research Institute, 2300 Tupper Street, Room PT 307, Montreal, Quebec H3H 1P3, Canada; e-mail: charles.scriver@mcgill.ca

Presented at the 2010 Annual Meeting of the Pediatric Academic Societies, Vancouver, British Columbia, Canada.

\section{Part II: Who Do I Serve?}

I have found this to be an excellent question to pose on waking in the morning. I tried to answer it in a general way on an earlier occasion, as recorded elsewhere (1). I have been able to answer that question in various personal ways while pursuing a hybrid career as a clinician-scientist. Although playing the role as "clinician," I was serving patients, families, and communities. In the other role as "scientist," I was serving knowledge whether it was transforming or translational in character.

As a biochemical geneticist, I recognize my debt to Archibald Garrod; to his work and to his concept of the "inborn error of metabolism." While Garrod introduced his concept a century ago, it took decades for the medical community to recognize its salience in medical education and practice. By comparison, biochemists were more receptive. Nonetheless, it took half a century for technologies to emerge that would identify the full spectrum of enzymatic and biochemical abnormalities involved in Garrod's four canonic inborn errors (albinism, alkaptonuria, cystinuria, and pentosuria). Enquiries embracing so many other disorders continue in the domains of biochemistry and cell biology, and these are being described in The Metabolic and Molecular Bases of Inherited Disease, a book now online in an attempt to keep pace with evolving knowledge and information (2). A century in time was also required for Garrod's other observations on the apparent genetic basis of inborn errors to find their place in the Human Genome Project and its related enterprises.

Garrod's thinking about individuality now underpins a thrust to create "personalized medicine" based on the results emerging from the Human Genome Project. From its viewpoint, the project suggests that every patient has what might be called an "orphan disease" or a unique state of health; and every physician could be a geneticist of sorts. When the clinician-scientist works in these contexts, private and public answers begin to emerge in response to that other great question in medicine: Why does this person have this disease now?

\section{Part III: Concepts Evolve}

In its simplest definition, science is an assault on our ignorance. Its legacies are concepts, technologies, and databases. Its tools are both general and particular: hypotheses and measurements; experiments and observations. Clinician-scientists can describe their work accordingly. In my own case, the work evolved with time and through various domains, beginning with the discovery and description of several "new" inborn errors of metabolism, then learning to work with genetic screening and testing in populations for early diagnosis of persons at risk. In turn, this led to simple, 
albeit crude, measurements of frequencies of particular inborn errors in the population. Therapeutic initiatives to neutralize the effects of the mutant gene were part of a new look at what can be done to help the patient and reduce the burden of the corresponding disorder in the population. Of course this involved an appreciation of factors in our physiology and biochemistry accounting for homeostasis and individuality. I found that phenylketonuria was an accessible and excellent model to illustrate corresponding concepts, the role of technologies, and the relevance of databases. In the course of studying phenylketonuria in various human populations, population genetics became part of our work and to support that work, we needed and used databases; which brought us into the domains of mutation taxonomy, nomenclature, and bioinformaticsfields I never anticipated would become interests of my own.

What I know now is very different from what I knew in 1961 when I started down the path of biochemical genetics. Garrod knew that the metabolic biochemistry of the human organism was a dynamic process, and by no means static when it functioned; he surmised that pathways existed along which substrates and products flowed under the control of catalysts becoming known as enzymes (3). One must also admire Garrod for seeing that inborn errors behaved as Mendelian phenotypes eventually exposing to enquiry the corresponding proteins and chemical reactions (4). Today, we see metabolism as a product of complex, active, scale-free networks, where explanations of disease (and of health) can be found (5). In the case of a model organism such as a yeast cell, and when animated by network thinking, it is now possible to speak of "genetic and epigenetic landscapes" (6) and also to learn that genetic redundancy is prominent, acting to buffer events such as mutation and stressful experience, disturbing to homeostasis. The language we use to describe domains of cellular function has become very "omic" (e.g. genome, transcriptome, metabolome, proteome). When packaged, as mysteriously as it is in the cell, the functional genome translates into the "phenome," interacting with the "environome." These are some new ways to describe the human individual. As Shakespeare put it- "such a piece of work is a man." If I were starting out anew today, I would hope to be better grounded in these new concepts knowing that biology and genetics have become dominant scientific domains of inquiry in the 21 st century.

\section{Part IV: Discovery and Wonder}

We are likely to witness more and more revelations in biology and genetics, each with some cause for further wonder and awe. Under these conditions, you and I will participate in a dialogue, one part of which addresses what is already known or becoming known in science and the practice of medicine; the other component being concerned with what is not known and will thus name our ignorance and be the ultimate focus of our science. The physicist Richard Feynman proposed that science is a continuing dialogue between sceptical inquiry and a sense of inexplicable mystery. There is no shortage of mystery when, for example, we contemplate how the genomes of maternal egg and paternal sperm combine to animate and direct the assembly of the complex creature we know as an infant.

We can maintain some level of humility during our voyages of discovery if we remember three questions posed by TS Eliot: "Where is the life we have lost in living? Where is the wisdom we have lost in knowledge? Where is the knowledge we have lost in information?"

The knowledge we accumulate can have several different attributes. There will be knowledge that I am not allowed to have (censorship), or it could be knowledge that I do not want to have (fear or a choice that favors ignorance); or it will describe what is known, accepted, and used; or it may be insufficiently known (call it the unknown) and will be the focus of our sceptical inquiries; or it may ultimately be unknowable and at the core of being and becoming.

\section{Part V: The Poet Speaks}

A poem by Osip Mandelstam, composed in 1909, speaks to the mystery of being. It haunts me. The poem has no title; it begins with these words in the English translation by James Greene and later published in book form (7).

"What shall I do with the body I've been given, So much at one with me, so much my own?"

Mandelstam continues with these thoughts

"For the calm happiness of breathing, being able To be alive, tell me where I should be grateful? I am gardener, flower too, and un-alone In this vast dungeon. My breath, my glow, you can already see On the windowpanes of eternity.

A pattern is imprinted there,

Unknown till now.

Let this muddle die down, this sediment flow out.

The lovely pattern cannot be crossed out."

Your life, my life, are mysterious gifts received while on the journey from Becoming to Being. The Howland Award is an unanticipated moment encountered while I am on my own particular journey. It is cause to pause, reflect, and be grateful.

\section{REFERENCES}

1. Scriver C 2006 Who do I serve? McGill J Med 9:84-87

2. Valle D, Beaudet AL, Vogelstein B, Kinzler KW, Antonarakis SE, Ballabio E (Eds) Scriver's Online Metabolic and Molecular Bases of Inherited Disease. Available at: http://www.ommbid.com. Accessed March 10, 2011

3. Garrod AE 1909 Garrod's Inborn Errors of Metabolism, Oxford University Press, London

4. Scriver CR 2008 Garrod's Croonian Lectures (1908) and the charter 'Inborn Errors of Metabolism': albinism, alkaptonuria, cystinuria, and pentosuria at age 100 in 2008. J Inherit Metab Dis 31:580-598

5. Goh KI, Cusick ME, Valle D, Childs B, Vidal M, Barabási AL 2007 The human disease network. Proc Natl Acad Sci U S A 104:8685-8690

6. Costanzo M, Baryshnikova A, Bellay J, Kim Y, Spear ED, Sevier CS, Ding H, Koh JL, Toufighi K, Mostafavi S, Prinz J, St Onge RP, VanderSluis B, Makhnevych T, Vizeacoumar FJ, Alizadeh S, Bahr S, Brost RL, Chen Y, Cokol M, Deshpande R, Li Z, Lin ZY, Liang W, Marback M, Paw J, San Luis BJ, Shuteriqi E, Tong AH, van Dyk N, Wallace IM, Whitney JA, Weirauch MT, Zhong G, Zhu H, Houry WA, Brudno M, Ragibizadeh S, Papp B, Pál C, Roth FP, Giaever G, Nislow C, Troyanskaya OG, Bussey H, Bader GD, Gingras AC, Morris QD, Kim PM, Kaiser CA, Myers CL, Andrews BJ, Boone C 2010 The genetic landscape of a cell. Science 327:425-431

7. Greene J 1978 Osip Mandelstam (poems chosen and translated by James Greene). Shambhala, Boston, pp 5 